\title{
Tekst prasowy jako bodziec do interakcji na lekcji języka obcego
}

\section{Wstęp}

Pobudzanie sprawności mówienia za pomocą różnych tekstów nie jest czymś nowym w glottodydaktyce ${ }^{1}$, ale specyfika komunikacyjna tekstu prasowego (w tym opracowaniu rozumianego jako każdy tekst dziennikarski przynależący do odpowiedniego gatunku prasowego), czyli sposób prezentacji rzeczywistości, sprzyja takiemu rozwinięciu interakcji, w rezultacie którego znaczenia zawarte w tekście mogą być negocjowane przez uczących się. Mogą oni bowiem, na bazie swoich doświadczeń i wiedzy związanej z przedstawionym przez dziennikarza tematem, zajmować odmienne stanowisko, wprowadzać nowe wątki do dyskusji. Istotne jest, że tekst prasowy ma potencjał, by zainicjować interakcję związaną, z jednej strony, $\mathrm{z}$ przedstawieniem rzeczywistego świata, $\mathrm{z}$ drugiej zaś - stanowi cenną bazę leksykalną pozwalającą na wzbogacanie dyskusji o fragmenty autentycznego języka.

W artykule wykorzystano fragmenty polskich tekstów prasowych, mimo to proponowane strategie pracy są $\mathrm{w}$ gruncie rzeczy uniwersalne, niezależnie od nauczanego języka. Inną rzeczą pozostaje jego trudność oraz kwestia poziomu uczących się; są to jednak problemy odnoszące się do umiejętnego doboru materiału dydaktycznego.

${ }^{1}$ Zob. np. D. Nunan, Language Teaching Methodology. A Textbook for Teachers, London 1995; A. Dąbrowska, M. Pasieka, Metody pracy z tekstem w nauczaniu język a polskiego jako obcego, [w:] Metodyka a nauka o literaturze i nauka o języku, red. D. Michułka, K. Bakuła, Wrocław 2005; A. Rabiej, Teksty użytkowe w nauczaniu języka polskiego jako obcego, „Acta Universitatis Lodziensis. Kształcenie Polonistyczne Cudzoziemców” 2010, nr 17; Ch. Johnes, Literature, Spoken Language and Speaking Skills in Second Language Learning, Cambridge 2019. 


\section{Mówienie i interakcja}

Interakcja na lekcji języka obcego może przybierać różne formy, niemniej jednak jej efektem będzie nie tylko pewna ilość wypowiedzi ustnych ucznia bądź całej grupy, lecz także wzajemnie zrozumienie wyprodukowanych komunikatów. Można stwierdzić, że udana interakcja na lekcji to taka, gdy uczniowie rozumieją się, a świadczy o tym na przykład adekwatne dostosowywanie wypowiedzi na kolejnych etapach rozmowy, czyli mówienie na temat (ciągłość tematyczna) oraz reagowanie (odpowiednie) na pytania lub wypowiedzi innych uczestników rozmowy. Dotyczy to zarówno dłuższych, złożonych dyskusji, jak i prostych reakcji dialogowych typu pytanie i odpowiedź. Niezależnie od długości, skomplikowania dialogów oraz poziomu znajomości języka mówienie w języku obcym jest sprawnością wymagającą zaangażowania za każdym razem poważnego potencjału poznawczego nadawcy ${ }^{2}$. Uczeń musi najpierw stworzyć reprezentację mentalną wypowiedzi, a następnie ją zwerbalizować, zwracając w dodatku uwagę na jej warstwę dźwiękową, co wymaga między innymi znajomości wymowy. Co więcej, zakłada się, że uczeń, mówiąc w języku obcym, posługuje się swego rodzaju interjęzykiem (interlanguage), który przypomina cechy języka rodowitego mówcy, ale nie jest identyczny ${ }^{3}$.

Jak wspomniano, mówienie w wielu sytuacjach komunikacyjnych jest reakcją na zadane uprzednio pytanie, a zatem następstwem jego zrozumienia. $Z$ kolei za prawidłowe odczytanie sensu pytania odpowiada sprawność słuchania. To wszystko składa się na złożoność interakcji, w której sprawność mówienia jest tylko jednym z nieodłącznych elementów. Interakcja może łączyć jednocześnie kilka sprawności językowych, a — jak sugeruje Stephen Krashen ${ }^{4}$ — ,nabywamy biegłości w mówieniu nie przez praktykę w konwersacji, lecz przez rozumienie wypowiedzi, przez słuchanie i czytanie". Z tej między innymi przyczyny nauczanie mówienia staje się dla wielu nauczycieli trudnym zadaniem ${ }^{5}$. Także uczniowie dość powszechnie tak postrzegają mówienie. Przyczyny tego są różne: brak wystarczających umiejętności językowych, niepełna znajomość słownictwa w danym obszarze tematycznym, jak również blokada przed mówieniem. Ostatnie zjawisko, dość częste na lekcjach, nawiązuje do zagadnienia niepewności językowej (language anxiety) ${ }^{6}$, która w skrajnych wypadkach znacznie utrudnia uczenie się języka obcego.

${ }^{2}$ Zob. A. Burns, Research and the teaching of speaking in the second language classroom, [w:] E. Hinkel, Handbook of Research in Second Language Teaching and Learning, t. 3, New York 2017, s. 245-246; A. Fromkin, N.B. Ratner, Wytwarzanie mowy, [w:] Psycholingwistyka, przeł. J. Bobryk, red. J.B. Gleason, N.B. Ratner, Gdańsk 2005.

3 Zob. E. Tarone, Speaking in a second language, [w:] The Handbook of Research in Second Language Teaching and Learning, red. E. Hinkel, Mahwah, London 2005, s. 485-486.

${ }^{4}$ S. Krashen, Principles and Practice in Second Language Acquisition, Oxford 1982, s. 60 (przeł. J.P.).

${ }^{5}$ A. Burns, op. cit., s. 242.

${ }^{6}$ E.K. Horwitz, M.B. Horwitz, J. Cope, Foreign Language Classroom Anxiety, „, The Modern Language Journal" 70, 1986, nr 2. 
Obecnie wiadomo, że poza ogólnymi możliwościami intelektualnymi ucznia procesy motywacyjne, pewne aspekty sytuacyjne związane z samopoczuciem, nastawienie do uczenia się konkretnego języka lub formy jego nauczania czy nawet relacja między uczniem a nauczycielem wpływają na efektywność edukacji i niewątpliwie mogą przekładać się na sprawność mówienia.

Ponadto mówienie jest formą prezentacji swoich umiejętności językowych przed nauczycielem oraz innymi uczącymi się, z czym wiąże się ryzyko ewentualnej oceny. Niektórzy nauczyciele zapewne spotkali się z różnymi formami wzajemnego krytykowania poziomu tej sprawności wśród uczniów. Takie zachowania są łatwą drogą do niepowodzenia. Zadaniem nauczyciela w tej sytuacji jest łagodzenie skutków występowania naturalnej u wielu uczących się bariery przed mówieniem w języku obcym, między innymi przez stworzenie warunków na lekcji, które będą motywowały do wypowiadania się. Luiza Ciepielewska ${ }^{7}$ wskazuje, że jednym z czynników wpływających na motywację jest materiał służący do nauczania. Jak zostanie pokazane w dalszej części artykułu, odpowiednio dobrany tekst prasowy zwiększa szansę na przeprowadzenie ciekawej lekcji, ale przede wszystkim umożliwia zaistnienie komunikacji ustnej.

\section{Jak wykorzystać tekst prasowy w rozwijaniu interakcji?}

Rola tekstu w nowocześnie realizowanym procesie dydaktycznym nie sprowadza się do ilustrowania zagadnień gramatycznych ani systematyzowania leksyki — ma on w głównej mierze rozwijać sprawność czytania ze zrozumieniem. Poza tym czytanie tekstu można przyrównać do rozmowy autora z czytelnikiem ${ }^{8}$. Podobnie myślał już Michaił Bachtin ${ }^{9}$, pisząc o rozumieniu współodpowiadającym, które jakkolwiek w trakcie lektury jest z natury rzeczy utajone (rozumienie współodpowiadające milczące), to jednak może oddziaływać na późniejsze zachowania (reakcje językowe). Ta idea będzie przyświecać proponowanej tutaj koncepcji pracy z tekstem prasowym, który jako autentyczny materiał dydaktyczny ma stanowić punkt wyjścia do nauczania sprawności mówienia opartego na interakcji.

Hanna Komorowska ${ }^{10}$ w dobrze znanym nauczycielom języków obcych podręczniku zaznacza, że jednym z podstawowych warunków w nauczaniu tej sprawności jest ,zapewnienie bodźca, który zachęci uczniów do wypowiedzi, czyli tzw. elicytacja". Kontakt ze słowem pisanym ma zatem niejako sprowokować do mówienia. Autentyczny tekst prasowy wymienia się jako jeden z ma-

${ }^{7}$ L. Ciepielewska, Zu ausgewählten unterrichtsbeeinflussenden Faktoren, „Scripta Neophilologica Posnaniensia" 4, 2004.

${ }^{8}$ Por. M. Gaszyńska-Magiera, Teksty prasowe w nauczaniu języka polskiego jako obcego, [w:] Tekst w mediach, red. K. Michalewski, Łódź 2002, s. 212.

${ }^{9}$ M. Bachtin, Estetyka twórczości słownej, przeł. D. Ulicka, Warszawa 1986, s. 359-360.

${ }^{10}$ H. Komorowska, Metodyka nauczania języków obcych, Warszawa 2005, s. 197. 
teriałów dydaktycznych, który inicjuje komunikację werbalną na lekcji ${ }^{11}$. Takie podejście zakłada dodatkowo możliwość włączenia w wypowiedzi ucznia treści przejętych z tekstu; chodzi o struktury gramatyczne, leksykę, ale jednocześnie warstwę pozajęzykową odnoszącą się do świata przedstawionego w tekście. Trzeba pamiętać, że teksty prasowe mają duży potencjał ukazywania rzeczywistości pozajęzykowej. Realia cywilizacyjne i kulturowe transmitowane przez teksty prasowe odwzorowują tak zwany językowy obraz świata oraz są rozpoznawane przez wspólnotę komunikacyjną, albowiem posługuje się ona konkretnym językiem, utrwalając w nim wiedzę czy też codzienne doświadczenia ${ }^{12}$. W ten sposób tekst prasowy sprzyja poszerzaniu wiedzy ucznia, a jednocześnie zachęca do wyrażania opinii, w tym polemiki. Przejście od lektury do dyskusji, która stanowi niejako ustne przetworzenie przez uczniów tekstu dziennikarskiego, wpisuje się w działania komunikacyjne zakładane $\mathrm{w}$ podejściu zadaniowym ${ }^{13}$. Partnerzy interakcji, rozmawiając o tekście prasowym, tworzą kolejne wypowiedzi, w których mogą pojawić się między innymi komentarz ( $w$ tym ocena, odniesienie do własnych doświadczeń), odpowiedzi na pytania (jeśli takie zostały uwzględnione w zadaniu lub jeśli występują jako naturalny element dialogu). Na uwagę zasługuje przy tej okazji kwestia specyfiki języka mówionego. Wypowiedzi ustne uczniów mogą zawierać różne typy błędów, co w niektórych przypadkach wymaga interwencji nauczyciela, który powinien zachęcać do autokorekty, na przykład zadając pytanie: „Jak można to powiedzieć inaczej?”. Warto, by nauczyciel proponował uczniom stosowanie w komunikacji werbalnej leksyki pochodzącej z tekstu prasowego (zwłaszcza w formie wyrażeń i zwrotów). Wręczenie uczniom karteczek z wynotowanym słownictwem lub krótkie ćwiczenie (na przykład uzupełnianie wybranym słownictwem zdań z lukami) tuż przed rozpoczęciem rozmowy zapewne zwiększy szansę na posłużenie się nową leksyką.

Wobec tego wybór tekstu i określenie technik pracy podczas lekcji powinny pozwolić nauczycielowi tak zaplanować, a następnie poprowadzić lekcję, aby wręcz naturalnym następstwem lektury była rozmowa. Najpierw należy jednak zapoznać się z pewnymi właściwościami tekstów prasowych, dzięki którym wybór stanie się łatwiejszym zadaniem, a w dalszej kolejności przemyśleć strategię wykorzystania tekstu na lekcji — chodzi o przygotowanie zadań, które wprowadzą ucznia w tematykę, ułatwią zrozumienie, a w końcu — zmobilizują do mówienia.

${ }^{11}$ A. Seretny, E. Lipińska, ABC metodyki nauczania języka polskiego jako obcego, Kraków 2005, s. 181.

12 Por. np. J. Anusiewicz, A. Dąbrowska, M. Fleischer, Językowy obraz świata i kultura. Projekt koncepcji badawczej, „Język a Kultura” 2000, nr 13, s. 25.

${ }^{13}$ ESOKJ, Europejski system opisu kształcenia językowego - uczenie się, nauczanie, ocenianie, przeł. W. Martyniuk, Warszawa 2003. 


\subsection{Cechy tekstów prasowych w kontekście nauczania sprawności mówienia i interakcji}

Żeby samodzielnie planować pracę z tekstem prasowym i wykorzystać jego potencjał do budowania przyszłej interakcji, potrzebna jest przynajmniej ogólna wiedza na temat cech tekstów prasowych. Umiejętność ich dostrzegania pozwala, z jednej strony, zrozumieć swego rodzaju komunikacyjną funkcjonalność przekazu, czyli mieć świadomość, na przykład dlaczego autor napisał taki, a nie inny tekst, w jakim celu użył wybranych środków językowych oraz co chciał przez to osiągnąć — jaki efekt wywołać u czytelnika. Z drugiej — te same cechy w odniesieniu do nauczania języka obcego niejako nakierowują nauczyciela, na co powinien zwrócić uwagę uczniom, które elementy tekstu będą dla nich ciekawe, z jakiegoś powodu istotne, trudne; co z tego stanie się początkiem konwersacji które elementy będą wywoływały reakcje uczniów, a które mogłyby się znaleźć w przyszłych wypowiedziach. Nie należy zakładać, że praca z tekstem dziennikarskim przypomina tę z innymi formami wypowiedzi pisemnej, na przykład przygotowanymi na potrzeby podręcznika kursowego. Po pierwsze, tekst prasowy jest wytworem autentycznym z konkretną strategią komunikacyjną, która sprawia, że jego przetwarzanie wymaga dostrzeżenia przez ucznia różnych, nieraz niepodanych wprost, relacji intertekstualnych, czyli odnoszących się do szeroko pojętej rzeczywistości pozajęzykowej (niekoniecznie ujętej w konkretnym tekście), w której funkcjonują rozmaite postawy, stereotypy, kody kulturowe, ale też wiedza $\mathrm{z}$ różnych obszarów. Tekst prymarnie dydaktyczny z reguły zawiera niewielką ilość takich odniesień. Co więcej, teksty prasowe w zależności od gatunku dziennikarskiego pod wieloma względami różnią się od siebie.

Dzielą się one na grupę tekstów informacyjnych i publicystycznych, wśród których istnieją konkretne gatunki ${ }^{14}$. Do pierwszych zalicza się między innymi wzmiankę, notatkę, zapowiedź, sprawozdanie, raport, biogram, reportaż, przegląd prasy oraz wywiad, uznawany niekiedy za gatunek pograniczny. Wśród drugich wymienia się między innymi artykuł publicystyczny, artykuł wstępny, felieton, komentarz, recenzję, esej i reportaż. Każda grupa wraz z przynależnymi jej gatunkami ma określony cel komunikacyjny ${ }^{15}$. Jak sama nazwa wskazuje, teksty informacyjne przekazują informacje; publicystyczne zaś — upraszczając — służą komentowaniu i wyrażaniu opinii względem opisywanej rzeczywistości, mogą odwoływać się do emocji odbiorców, jak również mieć na celu wywołanie określonych emocji ${ }^{16}$. Podział ten daje już pewne wyobrażenie o tym, jakie treści i w jaki sposób będą przedstawiane.

14 Zob. M. Wojtak, Gatunki prasowe, Lublin 2004.

15 Por. np. A. Duszak, Tekst, dyskurs, komunikacja międzykulturowa, Warszawa 1998, s. 213; H.H. Lüger, Pressesprache, Tübingen 1995, s. 45-46.

16 Por. H.H. Lüger, op. cit., s. 66 n. 
Przykładowo nauczyciel, wybierając gatunek informacyjny, będzie pracował z uczniami na obiektywnym opisie faktów. Gdy zaś zdecyduje się na publicystykę, zaproponuje pracę z opiniami, wartościowaniem i nierzadko emocjami. Poza tym od gatunków informacyjnych należy oczekiwać raczej prostszego słownictwa i mniej złożonych konstrukcji gramatycznych; będą one też na ogół krótsze. Należałoby się spodziewać, że uczniowie, wchodząc w interakcję po lekturze tekstu informacyjnego, będą koncentrować się bardziej na analizie wydarzeń, odpowiadaniu na pytania w rodzaju: kto?, kiedy?, jak?, gdzie?, dlaczego?, natomiast interakcja uczniów po przeczytaniu felietonu czy reportażu będzie od nich wymagać na przykład wyrażenia opinii, odniesienia się do własnych przeżyć, podjęcia polemiki. Wypowiedzi w obu przypadkach będą się niewątpliwie różnić.

Teksty dziennikarskie, niezależnie od gatunku, mają podobną budowę: rozpoczynają się tytułem (nagłówkiem), potem przeważnie (nieobligatoryjnie) następuje krótkie wprowadzenie wytłuszczoną czcionką, czyli lid lub główka, a później właściwy tekst, nazywany korpusem. Tytuł i lid nawiązują do treści korpusu — dziennikarze bardzo często podkreślają w nich ważne treści, które znajdują swoje objaśnienie w tekście. Robią to, by wzbudzić zainteresowanie czytelników i zachęcić ich do lektury. Co więcej, szczególnie tytuły nie zawsze jednoznacznie zapowiadają, o czym będzie dany tekst. Trudno na przykład po samym tylko nagłówku Ptaki, horror trwa ${ }^{17}$ wnioskować, czego dotyczy tekst. Co ciekawe, tytuł może wywołać skojarzenia ze słynnym filmem Alfreda Hitchcocka. Dopiero lektura lidu zapowiada temat tekstu publicystycznego: „Co roku myśliwi zabijają około 200 tys. ptaków. Wyłącznie dla własnej rozrywki. Żadnych innych powodów polowania na ptaki nie ma". Łatwo zauważyć, że w lidzie została sformułowana subiektywna ocena, co jest dość typowym wyznacznikiem gatunku. Abstrahując od tego, że tytuł nieraz nie naprowadza na tematykę, jest on interesującym obiektem do ćwiczeń komunikacyjnych, również z racji rozmaitych zabiegów stylistycznych, na przykład modyfikacji utartych powiedzeń: „Człowiek — najlepszy przyjaciel psa”18, „Hulaj noga, piekła nie ma”19 itp.

Przykładowe wskazówki do pracy z tytułami są zawarte w dalszej części. Wracając natomiast do gatunków, trzeba jeszcze uwzględnić niektóre cechy mające znaczenie w dydaktyce języków obcych. Są to między innymi:

— zróżnicowanie tematyczne i nagromadzenie informacji (jak często pojawiają się odniesienia do wiedzy pozajęzykowej);

- zróżnicowanie stylistyczne wraz z warstwą pragmatyczną (będą to na przykład językowe sposoby wyrażania intencji, emocji i wartościowania);

- stopień trudności słownictwa (czy występują słowa rzadkie, specjalistyczne, archaiczne itp.);

— stopień złożoności składniowej (jakie występują konstrukcje gramatyczne).

17 „Polityka” 2019, nr 49.

18 „Zwierciadło” 2019, nr 10.

19 „Polityka” 2019, nr 17-18. 
Nie jest to na pewno kompletna lista, niemniej jednak od występowania tych cech w konkretnych tekstach prasowych będzie zależeć na przykład ich ogólny stopień trudności, a co za tym idzie - wysiłek ucznia konieczny do poprawnego zrozumienia przekazu.

Chcąc uczynić dowolny tekst prasowy podstawą interakcji na lekcji, trzeba dobrze przemyśleć strategię pracy. Im większe natężenie wymienionych cech gatunkowych, tym więcej starań należy dołożyć, by właściwie przygotować uczniów - najpierw do czytania ze rozumieniem, a potem do rozmowy po lekturze. Krótkie teksty informacyjne sprawdzą się $\mathrm{w}$ grupach nawet o niższym poziomie zaawansowania, z kolei publicystyczne nadają się dla bardziej zaawansowanych uczniów i prawdopodobnie stworzą więcej okazji do dyskusji, ponieważ zazwyczaj poruszają istotne problemy społeczne, zawierają komentarze autora, mają strukturę argumentacyjną, przybierają niejednokrotnie formę narracji odwołującej się do emocji. Ważną cechą przekazu prasowego $\mathrm{w}$ aspekcie glottodydaktycznym jest zróżnicowanie struktur leksykalnych; zwłaszcza związki frazeologiczne o różnym stopniu łączliwości stanowią materiał do tworzenia wypowiedzi. Uczeń, czytając różne gatunki prasowe, poznaje wiele słów, których często nie znajdzie w podręczniku kursowym; uczy się synonimów, sposobów łączenia wyrazów, a mając okazję do praktycznego użycia nowych form leksykalnych w mówieniu, poszerza swoje zasoby aktywnego słownictwa. Jak zostanie pokazane dalej, cechy gatunków prasowych znajdują swoje zastosowanie w zadaniach aktywujących komunikację werbalną.

\subsection{Dobór tekstu prasowego a planowanie interakcji na lekcji}

Teksty prasowe ilustrują autentyczne użycie języka. Nauczyciel, wybierając materiał na lekcję, podczas której przewiduje aktywność w mówieniu, nie musi proponować uczniom całego tekstu. Może on zostać skrócony, chociaż postuluje się stosowanie przede wszystkim tekstów prymarnych, bez wprowadzania w nich zmian $^{20}$. Ma to swoje uzasadnienie szczególnie wtedy, gdy skrócenie lub zbytnia adaptacja zmienia intencje autora lub nie oddaje w pełni sensu oryginału. Dla rozwoju sprawności mówienia autentyczność nie jest warunkiem koniecznym, warto jednak nie upraszczać słownictwa, jeśli w odczuciu nauczyciela grupa uczniów reprezentuje stosowny poziom. Za skracaniem lub nawet wyborem pojedynczych akapitów przemawia ograniczony czas lekcji. Ponadto z myślą o przyszłej interakcji wystarczy niekiedy ukazanie uczniom fragmentu lub wycinków kilku różnych tekstów o zbliżonej problematyce, ażeby jak najmniej czasu zabrała lektura, a uczniowie mogli skoncentrować się na sprawności mówienia.

Kwestia zaawansowania języka grupy docelowej jest kluczowa przy wyborze, ponieważ zbyt trudny tekst przez brak rozumienia w czasie lektury powoduje tylko

${ }^{20}$ A. Dunin-Dudkowska, A. Trębska-Kerntopf, Teksty prymarne, adaptowane $i$ sekundarne w nauczaniu języka polskiego jako obcego na poziomie średnim — problemy i postulaty, „Acta Universitatis Lodziensis. Kształcenie Polonistyczne Cudzoziemców” 1998, nr 10. 
niepotrzebną frustrację i z pewnością nie uda się w oparciu o taki materiał zainicjować mówienia. Nauczyciel znający grupę nie tylko wie, jaki jest jej poziom, lecz także zna jej potrzeby, temperament uczniów, ich zainteresowania oraz ogólną motywację do wypowiadania się. To wszystko ostatecznie ułatwi dokonanie wyboru.

Gatunek prasowy stanowi ze względu na określony cel komunikacyjny pewną podpowiedź dla nauczyciela. Co innego komunikuje krótka notatka prasowa, a zupełnie inną formę wypowiedzi reprezentuje felieton. Wywiad jako rozmowa między dziennikarzem a gościem może stać się dla pewnej grupy uczniów wartościowym materiałem do przeprowadzenia pogadanki.

Wybór tekstu prasowego powinien zawsze łączyć się z jego staranną analizą pod kątem słownictwa i stylu, złożoności gramatycznej, obecność informacji kulturowych. Trudne lub po prostu nowe słowa oraz środki stylistyczne najlepiej wprowadzić za pomocą ćwiczeń przed lekturą. Następnie nauczyciel może zaproponować wykorzystanie wybranego słownictwa w wypowiedziach. Szeroko pojęty przekaz kulturowy w tekstach prasowych dostarcza uczniom nowych wiadomości o obszarze cywilizacyjnym danego języka obcego, dodatkowo pozwala na zajęcie stanowiska wobec opisywanych zjawisk, poglądów innych ludzi itp. Chociaż znalezienie odpowiedniego tematu tekstu jest sprawą oczywistą, to jednak istotne będzie zaproponowanie uczniom czegoś możliwie ciekawego i aktualnego. Przekazy prasowe tracą na aktualności, co nie znaczy, że każdy starszy tekst będzie pozbawiony walorów dydaktycznych - istnieją takie, zwłaszcza z kręgu publicystyki, które poruszają problemy uniwersalne i wciąż nadające się do omawiania. Z kolei zestawienie kilku krótkich gatunków informacyjnych opublikowanych w różnych okresach, ale poświęconych podobnej tematyce jest dobrym pomysłem na dyskusję o wydarzeniach z przeszłości. Mogą to być na przykład notatki prasowe informujące o sukcesach sportowych. Warto dodać, że materiał może pochodzić z gazet codziennych, tygodników, miesięczników tak w wersji papierowej, jak i elektronicznej.

Wydaje się, że wybór tekstu prasowego, który ma spowodować interakcję, jest motywowany trzema kryteriami, które wzajemnie się uzupełniają: językowym, treściowym i glottodydaktycznym. W kryterium językowym mieszczą się takie czynniki, jak gatunek, styl, zróżnicowanie słownictwa i gramatyki. Kryterium treściowe obejmuje temat oraz przekazywaną wiedzę o świecie. Wreszcie kryterium glottodydaktyczne determinują między innymi długość, trudność, stopień autentyczności oraz aktualność.

\subsection{Metody pracy z tekstem rozwijające interakcję}

Założenia podejścia zadaniowego w nauczaniu języka obcego ${ }^{21}$ przewidują, że jego celem jest efektywna komunikacja, która integruje wszystkie sprawności

${ }^{21}$ Por. np. J.C. Richards, T.S. Rodgers, Approaches and Methods in Language Teaching, Cambridge 2002, s. 172; I. Janowska, Podejście zadaniowe do nauczania i uczenia się języków obcych. Na przyktadzie języka polskiego jako obcego, Kraków 2011, s. 33-34. 
językowe - nauczyciel sięga jak najczęściej po autentyczne materiały, a jego rolą staje się nauczanie w duchu interkulturowości. Podejście zadaniowe odpowiada przyjętemu $\mathrm{w}$ tym artykule sposobowi myślenia o nauczaniu sprawności mówienia poprzez lekturę tekstu dziennikarskiego. Taka zapośredniczona interakcja oznacza, że uczniowie przechodzą od czytania do mówienia, bazując przy tym na materiale językowym i wiedzy z lektury. Uczeń, rozmawiając o tym, co przeczytał, nabywa z czasem umiejętność rozpoznawania, jak teksty prasowe opisują rzeczywistość pozajęzykową — jakie mechanizmy językowe temu służą oraz jak wykorzystać je w komunikacji. Ten proces wiąże się z budowaniem świadomości językowej ${ }^{22}$. Oprócz tego uczeń, włączając do swoich wypowiedzi nowe struktury gramatyczno-leksykalne $\mathrm{z}$ autentycznego tekstu prasowego, przybliża uczenie się języka do naturalnych warunków akwizycji.

Praca ukierunkowana na zainicjowanie mówienia zaczyna się od lektury, chociaż w przypadku trudniejszych tekstów warto wcześniej przygotować ćwiczenia wprowadzające, mające na celu ułatwienie zrozumienia treści. Krótkie teksty, niewykraczające poza poziom uczniów, mogą od razu posłużyć jako bodziec do komunikacji. Wówczas celem wszelkich ćwiczeń jest zachęcenie ucznia do wypowiedzi. Takie ćwiczenia wymagają zawsze odniesienia do treści i obejmują pracę miedzy innymi z a) nagłówkami, b) nagłówkami i lidami lub fragmentami korpusu, c) całym tekstem lub jego fragmentami. Należy podkreślić, że przedstawiony wybór ćwiczeń jest tylko jednym z wielu możliwych. Nauczyciel może wprowadzać modyfikacje, tak by jak najlepiej zrealizować ostateczny cel, którym ma być zaistnienie interakcji; powinien jednak pamiętać o tym, iż konwersacja rządzi się innymi regułami niż sprawność czytania ze zrozumieniem. Stąd tak istotne jest stworzenie uczniom (stosownie do ich możliwości językowych) warunków do dyskusji, wymieniania się opiniami, przedstawiania swoich własnych poglądów itp.

\section{a) Ćwiczenie z nagłówkami}

Tytuły, podtytuły i śródtytuły to krótkie komunikaty, bardzo często skonstruowane tak, by zwrócić uwagę czytelnika. Same więc stanowią bodziec do dalszej lektury, a w nauczaniu języka obcego — do rozmowy. Efekt oddziaływania nagłówków wynika $\mathrm{z}$ różnych zabiegów stylistycznych. W ćwiczeniu chodzi o wypowiedzenie się na temat nagłówków.

Proszę omówić w klasie podane tytuły. O czym mogą być teksty o takich tytułach?

1. Kandydaci na ostatniej prostej ${ }^{23}$.

2. Święta po polsku ${ }^{24}$.

22 Zob. np. B. Tomlinson, Using Literature in Text-Driven Materials to Help Develop Spoken Language Awareness, [w:] Literature, Spoken Language and Speaking Skills in Second Language Learning, red. Ch. Jones, New York 2019.

23 „Gazeta Wyborcza” 24.06.2020.

24 „Newsweek” 2019, nr 48. 
3. Zajadanie problemu ${ }^{25}$.

4. Klimat, wielkie odliczanie ${ }^{26}$.

5. Sita sugestii ${ }^{27}$.

6. Polskie korki ${ }^{28}$.

Interakcja po tym pytaniu powinna doprowadzić do zebrania różnych pomysłów oraz wymiany poglądów. Dodatkowo nauczyciel może zapytać: „Który z tych tekstów chciałby/chciałaby pan/i przeczytać i dlaczego?”, co daje sposobność do kontynuowania rozmowy.

Ćwiczenie, przy odpowiednim doborze nagłówków, nadaje się na każdy poziom nauczania. Jest to dość prosty sposób zapoznania uczących się z autentycznym językiem (z prasy) i jednocześnie wywołania dyskusji. Na końcu dobrze jest podać tematykę tekstów. W trakcie wypowiedzi nauczyciel może zadawać dodatkowe pytania, na przykład „Dlaczego tak myślisz? Skąd masz takie skojarzenie?” (tytuły mogą poruszać wyobraźnię). Trzeba pamiętać, że tego rodzaju ćwiczenie dostarcza bardzo niewiele materiału leksykalnego, wobec czego przebieg dyskusji zależeć będzie w głównej mierze od umiejętności uczniów. Wartością ćwiczenia jest poznawanie przez uczniów sposobu, w jaki zestawianie wyrazów w nagłówkach wywołuje określone skojarzenie. Słowo „kandydat” w pierwszym nagłówku kojarzy się z ubieganiem się o stanowisko lub z rekrutacją na przykład do szkoły, w sporcie niekiedy — z perspektywą zwycięstwa (do podium, do tytułu mistrzowskiego itp.). Wyrażenie „ostatnia prosta” w świecie sportu oznacza końcowy etap na przykład wyścigu. Natomiast w omawianym tytule chodzi o ostatnie dni przed wyborami prezydenckimi w Polsce. Taki tytuł poza interesującym zestawieniem wyrazów przynosi jeszcze informację o realiach, aktualnych wydarzeniach, co jest ważnym elementem kształcenia kulturowego. Asocjacje, które powstaną po przeczytaniu ostatniego z tytułów, mogą być spowodowane przypadkowym podobieństwem brzmieniowym do wyrazu „korek”. Należy tutaj poczynić pewne wyjaśnienia. Tekst prasowy opisuje zjawisko korepetycji w Polsce, których potoczna nazwa, będąca zresztą derywatem ujemnym wyrazu „korepetycje”, to właśnie „korki”. Uczniowie mogą jednak znać inne wyrażenia z tym wyrazem, takie jak „korek do butelki” czy też „korek do zlewu, wanny, brodzika”, „korek na drodze”, „,bezpiecznik” (w instalacjach elektrycznych). Nauczyciel musi wyjaśnić, że pojęcia te nie są tożsame. Zapobiegnie to utrwaleniu błędnych skojarzeń. Poza tym opisany przykład stanowi ciekawy problem do omówienia z uczniami na zajęciach.

\footnotetext{
25 Ibidem.

26 „Polityka” 2019, nr 49.

27 Ibidem.

28 „Newsweek” 2019, nr 42.
} 


\section{b) Ćwiczenie z nagłówkami i lidem (lub fragmentem korpusu)}

W tym ćwiczeniu uczniowie najpierw łączą nagłówki z lidami lub fragmentami korpusów, do których nawiązują tytuły, a dopiero później pojawia się etap związany z reakcją werbalną.

Proszę dopasować tytuł do fragmentu tekstu.

1. Doładować świat ${ }^{29}$.

2. Outsiderka na wojnie $e^{30}$.

3. Terapeutyczny labirynt ${ }^{31}$.

4. Gdy spotkasz mieniaka, nie ruszaj się! $!^{32}$

A. Droga Olgi Tokarczuk do Nobla to historia pisarki, która po osiągnięciu sukcesu postanowiła wyjść poza swoją strefę komfortu i walczyć, by świat był lepszy.

B. Są tak piękne, jakby przybyły wprost $\mathrm{z}$ tropików, ale to nasze rodzime motyle. Jedne z najpiękniejszych w Polsce. Każdy ma szansę spotkać je w naszych lasach już od czerwca. Jeśli tylko zechcą się pokazać, bo z tym bywa różnie.

C. Psychoterapia jest dobra i może pomóc. Musisz tylko uważać, do kogo trafisz. W Polsce wciąż nie ma ustawowej definicji zawodu psychoterapeuty, a w samym środowisku toczy się spór o obowiązujące go reguły.

D. Opracowanie ogniw litowo-jonowych było technologiczną rewolucją. Te raz jednak czas na kolejne pomysły, jak dodać energii naszym urządzeniom.

Odpowiednio sformułowane pytania lub polecenia do pracy zachęcają do dialogu.

Proszę porozmawiać w klasie, jakich wydarzeń/problemów dotyczą teksty. Co może Pani/Pan o tym powiedzieć? Jakie jest Pani/Pana zdanie na ten temat?

To ćwiczenie w porównaniu z poprzednim dostarcza więcej materiału językowego do przyszłej rozmowy. Zanim uczniowie dopasują nagłówki do lidów bądź korpusów, mogą zostać poproszeni przez nauczyciela — tak samo jak w poprzednim ćwiczeniu — o próbę wyjaśnienia, co zapowiadają poszczególne tytuły, dzięki czemu ma szansę zaistnieć interesująca dyskusja. Szczególnie gdy uczniowie posiadają już pewną wiedzę z wybranych tematów. W zależności od potrzeb w wariancie tego ćwiczenia mogłyby też pojawić się dłuższe fragmenty albo poruszające ten sam obszar tematyczny, co znacznie systematyzuje słownictwo. Aktywność werbalna będzie w dużym stopniu zależeć od pytań po lekturze. Nauczyciel musi zdawać sobie sprawę z tego, że pytania nie mają na celu sprawdzenia, czy uczeń na przykład znajduje w tekście określone informacje, ponieważ nie chodzi tutaj o testowanie

\footnotetext{
${ }^{29}$ Ibidem.

${ }^{30}$ Ibidem.

31 „Tygodnik Powszechny” 2018, nr 50.

32 "Gazeta Wyborcza” 24.06.2020.
} 
czytania ze zrozumieniem, lecz uruchomienie zachowań interakcyjnych w grupie uczniów. Pytania muszą więc spełniać funkcję stymulującą, nie zaś testującą rozumienie. Niemniej jednak nauczyciel może poprosić, by w wypowiedziach pojawiły się konkretne zwroty czy nawet pojedyncze słowa, na przykład „wyjść poza strefę komfortu”, ,psychoterapia”. Przy dłuższych tekstach takich jednostek leksykalnych będzie znacznie więcej. Sugestia nauczyciela, że uczniowie mogą podczas rozmowy (dyskusji) spoglądać do tekstu, zwiększy szansę użycia niektórych słów. Pytania nawiązujące do materiału tekstowego mogą wykraczać poza jego zakres, na przykład „Co wiesz o Oldze Tokarczuk?”, „Dlaczego ludzie chodzą na psychoterapię?”. Oprócz dyskusji potencjalnym rezultatem tego ćwiczenia, zwłaszcza gdy uczniowie mają do dyspozycji dłuższy tekst, jest włączenie do wypowiedzi nowych jednostek leksykalnych oraz — dzięki odpowiedniemu pokierowaniu rozmową — zajęcie stanowiska dotyczącego konkretnego problemu. Wartością płynącą z wykorzystania odpowiednio dobranych tekstów dziennikarskich jest przekaz realioznawczy; fragmenty o Oldze Tokarczuk i polskim motylu dają uczącym się okazję do zdobycia nowej wiedzy o kraju. Pod względem językowym to ćwiczenie warto wprowadzać w grupach od poziomu A2, ponieważ występują tutaj wszystkie polskie przypadki, tryb rozkazujący, przykłady stopniowania, a nadto trudniejsze słownictwo.

\section{c) Ćwiczenie z całym tekstem}

Założenia metodyczne tego ćwiczenia pokrywają się po części z poprzednim ćwiczeniem. Nie przewiduje ono jednak dodatkowych czynności, jak łączenie tytułu z korpusem, ponieważ głównym celem powinna być koncentracja na jednym nierozdzielnym komunikacie prasowym.

Proszę przeczytać tekst.

\section{Będzie bonus za frekwencję}

Władze Łodzi zachęcają mieszkańców do udziału w wyborach prezydenckich. Jeśli 28 czerwca frekwencja w tym mieście przekroczy 60 proc., za darmo lub symboliczną złotówkę udostępnione będą liczne atrakcje. Podczas „weekendu darmowych atrakcji” będzie można skorzystać z oferty ogrodu botanicznego, muzeów, zoo i aquaparku. Bezpłatne będą też przejazdy MPK.

Nie wiadomo jeszcze, w który weekend zostaną wprowadzone zniżki. Decyzja ma być ogłoszona po wyborach prezydenckich ${ }^{33}$.

Proszę porozmawiać.

Co pani/pan sądzi o pomyśle władz miasta, by zachęcić mieszkańców do pójścia na wybory? Jak to wygląda w pani/pana kraju?

Tutaj można stawiać dodatkowe pytania mające rozwinąć konwersację, na przykład „Czy trzeba/warto/powinno się chodzić na wybory?”.

W ćwiczeniu wykorzystano notatkę prasową, która należy do najprostszych gatunków informacyjnych. Zaproponowany został aktualny temat dotyczący wy-

33 „Gazeta Wyborcza” 24.06.2020. 
darzeń w kraju. Taki materiał prawdopodobnie wzbudzi zainteresowanie uczniów. Przy wprowadzeniu kilku słów i omówieniu niektórych kwestii gramatycznych notatka nadaje się nawet dla grup, które intensywnie pracują na poziomie A1. Pracę można zacząć od pokazania nagłówka i postawienia pytania: „O czym będzie tekst o takim tytule?”. Słowo „bonus” niekoniecznie będzie znane wszystkim uczącym się, a jest kluczem do zrozumienia korpusu - nazywa korzyści, które mają być następstwem wysokiej frekwencji. Praca z całym tekstem umożliwia dokładniejsze przedyskutowanie wybranego tematu. W grupach na wyższych poziomach zaawansowania (od B1) warto sięgać po trudniejsze gatunki publicystyczne, na przykład felieton.

\section{Podsumowanie}

W rozważaniach starano się pokazać, że teksty prasowe stanowią wartościowy materiał dydaktyczny, stymulujący interakcję werbalną na lekcji. Takie ich zastosowanie przyczynia się do jednoczesnego kształtowania dwóch sprawności językowych: czytania ze zrozumieniem i mówienia w formie interakcji między uczniami. Korzyści dla uczniów podejmujących aktywność werbalną na lekcji dzięki lekturze różnych gatunków dziennikarskich to, z jednej strony, większe prawdopodobieństwo przyswojenia nowych form leksykalnych osadzonych w różnych kontekstach oraz poszerzanie własnego leksykonu, zrozumienie pewnych (gatunkowych) funkcji komunikacyjnych, co może z czasem wpływać na urozmaicenie form wypowiedzi ustnych i pisemnych, uczenie się w praktycznym użyciu struktur gramatycznych, zwłaszcza jeśli nauczyciel steruje interakcją tak, by uczniowie stosowali w wypowiedziach wybrane formy. Z drugiej strony, teksty prasowe są bogatym źródłem wiedzy o kraju i kulturze obszaru języka docelowego, skłaniają przy tym do rozmowy na temat podobieństw i różnic kulturowych, pozwalają na wyrażenie opinii uczniów na temat wielu wydarzeń i zjawisk w danym kraju.

Rola nauczyciela sprowadza się przede wszystkim do starannego wyboru. Na podstawie obserwacji poziomu swoich uczniów musi on uwzględnić gatunek, ocenić trudność wybranego tekstu, jego wartość dydaktyczną (tematykę, nagromadzenie słownictwa, aspekty kulturowe przekazu), podjąć decyzję dotyczącą typów ćwiczeń i ewentualnego skrócenia. Istotnym zadaniem nauczyciela jest kierowanie komunikacją ustną na lekcji, zadawanie pytań, które będą motywować do wypowiedzi, negocjowania wybranych treści, ukazywania różnych (nawet przeciwstawnych) poglądów, interpretacji, wniosków.

Nie ulega wątpliwości, że dobrze dobrany tekst prasowy, wraz z zestawem ćwiczeń oraz aktywną i wspierającą postawą nauczyciela, nie tylko zmotywuje uczących się do podejmowania interakcji w języku obcym, ale też przyczyni się do polepszenia tej ważnej sprawności. 


\section{Bibliografia}

Anusiewicz J., Dąbrowska A., Fleischer M., Językowy obraz świata i kultura. Projekt koncepcji badawczej, „Język a Kultura” 2000, nr 13.

Bachtin M., Estetyka twórczości słownej, przeł. D. Ulicka, Warszawa 1986.

Burns A., Research and the teaching of speaking in the second language classroom, [w:] E. Hinkel, Handbook of Research in Second Language Teaching and Learning, t. 3, New York 2017.

Ciepielewska L., Zu ausgewählten unterrichtsbeeinflussenden Faktoren, „Scripta Neophilologica Posnaniensia" 4, 2004.

Dąbrowska A., Pasieka M., Metody pracy z tekstem w nauczaniu język a polskiego jak o obcego, [w:] Metodyka a nauka o literaturze i nauka o języku, red. D. Michułka, K. Bakuła, Wrocław 2005.

Dunin-Dudkowska A., Trębska-Kerntopf A., Teksty prymarne, adaptowane i sekundarne w nauczaniu języka polskiego jako obcego na poziomie średnim — problemy i postulaty, „Acta Universitatis Lodziensis. Kształcenie Polonistyczne Cudzoziemców” 1998, nr 10.

Duszak A., Tekst, dyskurs, komunikacja międzykulturowa, Warszawa 1998.

ESOKJ, Europejski system opisu kształcenia językowego - uczenie się, nauczanie, ocenianie, przeł. W. Martyniuk, Warszawa 2003.

Fromkin A., Ratner N.B., Wytwarzanie mowy, [w:] Psycholingwistyka, przeł. J. Bobryk, red. J.B. Gleason, N.B. Ratner, Gdańsk 2005.

Gaszyńska-Magiera M., Teksty prasowe w nauczaniu języka polskiego jako obcego, [w:] Tekst w mediach, red. K. Michalewski, Łódź 2002.

Horwitz E.K., Horwitz M.B., Cope J., Foreign Language Classroom Anxiety, „The Modern Language Journal" 70, 1986, $\mathrm{nr} 2$.

Janowska I., Podejście zadaniowe do nauczania i uczenia sięjęzyków obcych. Na przykładzie języka polskiego jako obcego, Kraków 2011.

Johnes Ch., Literature, Spoken Language and Speaking Skills in Second Language Learning, Cambridge 2019.

Komorowska H., Metodyka nauczania języków obcych, Warszawa 2005.

Krashen S., Principles and Practice in Second Language Acquisition, Oxford 1982.

Literature, Spoken Language and Speaking Skills in Second Language Learning, red. Ch. Jones, New York 2019.

Lüger H.H., Pressesprache, Tübingen 1995.

Nunan D., Language Teaching Methodology. A Textbook for Teachers, London 1995.

Seretny A., Lipińska E., ABC metodyki nauczania języka polskiego jako obcego, Kraków 2005.

Rabiej A., Teksty użytkowe w nauczaniu języka polskiego jako obcego, „Acta Universitatis Lodziensis. Kształcenie Polonistyczne Cudzoziemców” 2010, nr 17.

Richards J.C., Rodgers T.S., Approaches and Methods in Language Teaching, Cambridge 2002.

Tarone E., Speaking in a second language, [w:] The Handbook of Research in Second Language Teaching and Learning, red. E. Hinkel, Mahwah, London 2005.

Tomlinson B., Using Literature in Text-Driven Materials to Help Develop Spoken Language Awareness, [w:] Literature, Spoken Language and Speaking Skills in Second Language Learning, red. Ch. Jones, New York 2019.

Wojtak M., Gatunki prasowe, Lublin 2004. 